\title{
Diversity of algae and lichens in biological soil crusts of Ardley and King George islands, Antarctica
}

\author{
NADINE BORCHHARDT ${ }^{1}$, ULF SCHIEFELBEIN ${ }^{2}$, NELIDA ABARCA ${ }^{3}$, JENS BOY ${ }^{4}$, \\ TATIANA MIKHAILYUK ${ }^{\mathbf{1}, \mathbf{5}}$, HARRIE J.M. SIPMAN ${ }^{3}$ and ULF KARSTEN ${ }^{\mathbf{1}}$ \\ ${ }^{1}$ University of Rostock, Institute of Biological Sciences, Applied Ecology \& Phycology, Albert-Einstein-Straße 3, \\ D-18059 Rostock, Germany \\ ${ }^{2}$ Blücherstraße 71, D-18055 Rostock, Germany \\ ${ }^{3}$ Botanic Garden and Botanical Museum Berlin-Dahlem, Freie Universität Berlin, Königin-Luise-Straße 6-8, D-14195 Berlin, Germany \\ ${ }^{4}$ Leibniz Universität Hannover, Institute of Soil Sciences, Herrenhäuser Straße 2, D-30419 Hannover, Germany \\ ${ }^{5}$ M. H. Kholodny Institute of Botany, National Academy of Sciences of Ukraine, Tereschenkivska St. 2, Kyiv UA-01001, Ukraine \\ nadine.borchhardt@uni-rostock.de
}

\begin{abstract}
In the present study the biodiversity of the most abundant phototrophic organisms forming biological soil crust communities were determined, which included green algae, diatoms, yellow-green algae and lichens in samples collected on Ardley and King George islands, Maritime Antarctic. The species were identified by their morphology using light microscopy, and for lichen identification thin layer chromatography as also used to separate specific secondary metabolites. Several sources of information were summarized in an algae catalogue. The results revealed a high species-richness in Antarctic soil crust communities with 127 species in total. Of which, 106 taxa belonged to algae (41 Chlorophyta, nine Streptophyta, 56 Heterokontophyta) and 21 to lichens in 13 genera. Moreover, soil crust communities with different species compositions were determined for the various sampling locations, which might reflect microclimatic and pedological gradients.
\end{abstract}

Received 10 August 2016, accepted 9 November 2016, first published online 12 January 2017

Key words: cryptogams, diatoms, green algae, South Shetland Islands, species composition, yellow-green algae

\section{Introduction}

Biological soil crusts (BSCs) represent an association of diverse organisms and soil particles that vary in size as well as composition. They are formed by cyanobacteria, algae, lichens, bacteria, microfungi and bryophytes in different proportions. These organisms live within the upper few centimetres of the soil and also form a thin layer on the soil surface, where the mucilaginous sheaths and excreted extracellular polymeric substances (EPS) produced by filamentous cyanobacteria and algae stick the soil particles together (Büdel \& Colesie 2014, Weber et al. 2016). However, coccoid microorganisms are also important in the development of BSCs and are mainly represented by high species numbers of green algae (Belnap et al. 2001). Members of the green algal genus Coccomyxa Schmidle are frequently observed in BSCs of Antarctica (Pfaff et al. 2016) and diatoms and Xanthophyceae are also present in BSCs (Flechtner et al. 2008).

Biological soil crusts represent pioneer communities that have important ecological functions in soil stabilization to reduce wind and water erosion (Belnap \& Gillette 1998), in hydrological processes for water retention (Belnap 2006), in primary production and nitrogen fixation (Evans \& Lange 2001), in biogeochemistry, in geomorphology (Evans \& Belnap 1999), and in nutrient cycles (Wu et al. 2013, reviewed in Büdel \& Colesie 2014). These cryptogamic communities also have a positive influence on the establishment and growth of vascular plants (Harper \& Belnap 2001).

These communities are heterogeneous and vary in their species compositions. Different types exist, which can be macroscopically distinguished by colour and morphology as well as microscopically by both the taxa occurring and species numbers (Weber et al. 2016, Williams et al. 2016). The establishment and development of BSCs is based on the substrate and controlled by climatic factors (Elster et al. 1999). These cryptogamic communities are distributed worldwide in all climate zones and occur mostly in nutrient-poor and extreme habitats, such as hot and cold semiarid or arid areas (Büdel \& Colesie 2014). They are found both in Arctic Svalbard (Williams et al. 2016) and Continental Antarctica (Colesie et al. 2014). However, BSCs have been generally poorly studied in the Polar Regions, particularly in Antarctica, until now (Green \& Broady 2001).

Studies on Antarctic terrestrial vegetation have been, thus far, mainly focused on bryophytes and lichens (Peat et al. 2007), although the ice-free soil also contains different taxa of algae (Broady 1996). The soil algae of Antarctic edaphic communities were reviewed in Broady (1996), but those associated with BSCs in Maritime 


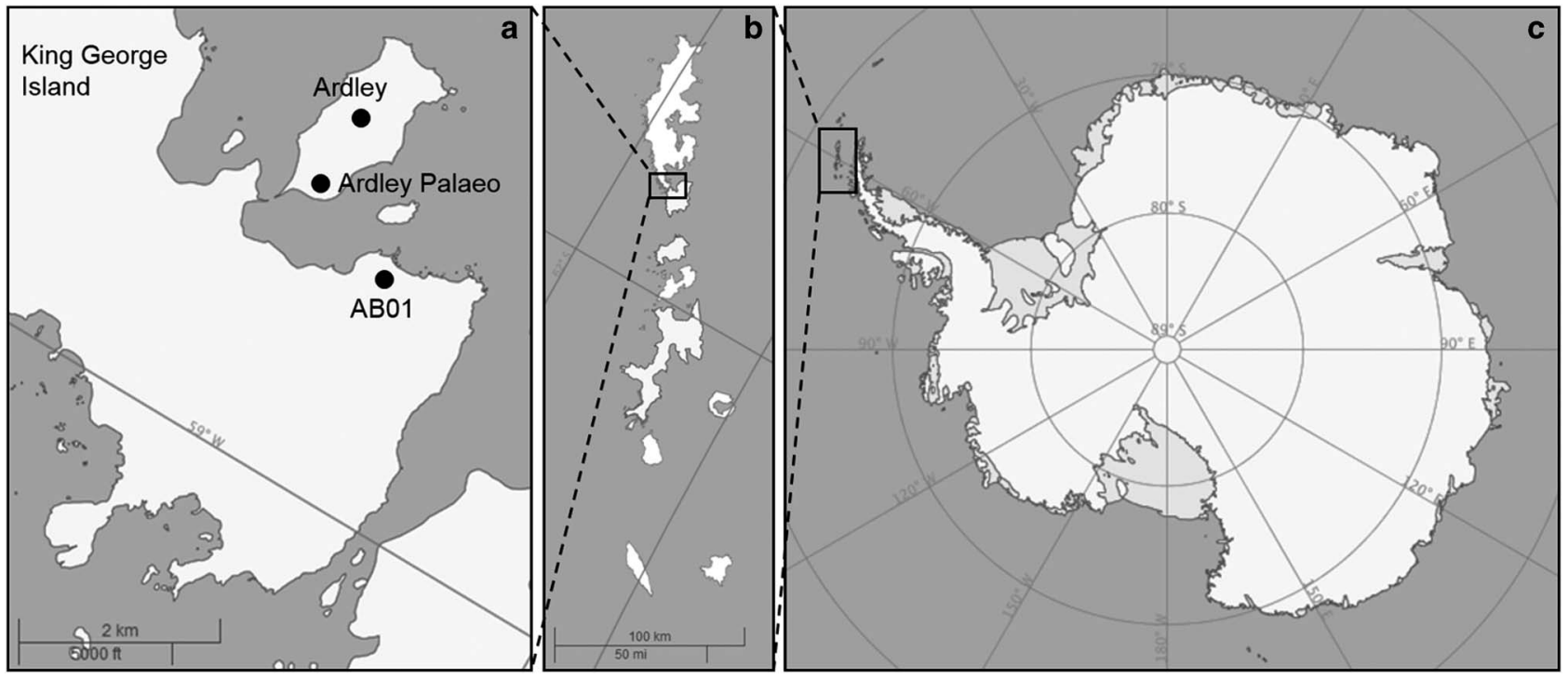

Fig. 1. Maps of the biological soil crust sample sites. a. The three sample sites on Ardley Island and King George Island, b. the South Shetland Islands, c. Antarctica.

Antarctic are almost unstudied (Green \& Broady 2001). Colesie et al. (2014) recently investigated BSCs in the Darwin Mountains region, Continental Antarctica, and found low BSC coverage of the soil surface $(0.8-3.3 \%)$ with species-poor crusts composed of few green algal lichens, cyanobacteria and several species of green algae. However, there remains a lack of knowledge on the algal component of BSCs in Antarctica.

Here, we present the results of a study that investigated the biodiversity of algae and lichens of BSCs collected on King George Island and Ardley Island, Maritime Antarctic, revealing the composition and proportion of green algae, diatoms, xanthophytes and lichens found in these BSCs.

\section{Materials and methods}

\section{Study sites}

Ardley Island and King George Island belong to the South Shetland archipelago in the Southern Ocean (Fig. 1). The South Shetland archipelago $\left(61^{\circ}-63^{\circ} \mathrm{S}\right.$, $54^{\circ}-63^{\circ} \mathrm{W}$ ) is separated from the Antarctic Peninsula by the Bransfield Strait and from South America by the Drake Passage. This area has the mildest climate of the Antarctic region because it constitutes the most northerly part of the continent and it is strongly influenced by the Antarctic Circumpolar Current. The meteorological data from the Russian Bellingshausen Station at Collins Harbour, King George Island, indicate an annual mean air temperature of $-2.5^{\circ} \mathrm{C}$ and mean precipitation of $701.3 \mathrm{~mm} \mathrm{yr}^{-1}$ (measurement period: 1948-2011, Kejna et al. 2013).

In February 2014, BSCs were collected at three different sampling sites. Two were located on Ardley
Island ('Ardley' $62^{\circ} 12^{\prime} 45.91 " \mathrm{~S}, \quad 58^{\circ} 55^{\prime} 53.31 " \mathrm{~W}$ to $62^{\circ} 12^{\prime} 49.02^{\prime \prime S}, \quad 58^{\circ} 56^{\prime} 13.32^{\prime \prime} \mathrm{W}$ and 'Ardley Palaeo' $\left.62^{\circ} 12^{\prime} 46.55^{\prime \prime S}, 58^{\circ} 56^{\prime} 48.98^{\prime \prime} \mathrm{W}\right)$ and one on the Fildes Peninsula, King George Island ('AB01' 62 ${ }^{\circ} 13^{\prime} 18.93$ "S, $\left.58^{\circ} 57^{\prime} 17.37^{\prime \prime} \mathrm{W}\right)$, which has the largest ice-free areas in the Maritime Antarctic (Fig. 1). These three sampling stations roughly follow an age gradient. 'Ardley' forms part of the slopes at Ardley Island itself, believed to have never been glaciated throughout the Holocene (Mäusbacher 1991). 'AB01' is well dated due to its direct vicinity to the Yanou and Gaoshan lakes (6000-7000 yr BP, Watcham et al. 2011). 'Ardley Palaeo' lies on a raised storm beach built up by isostatic uplift and is dated to $4400-2300 \mathrm{yr}$ BP (Boy et al. 2016). 'Ardley' is a BSC that grows along a tributary to Ardley Lake, which meanders on the partially frozen soils, leading to temporary bogs and by this to saturated water conditions. In contrast, 'Ardley Palaeo' BSC developed on a raised storm beach, which typically has larger pebbles as precursors of soil development, exhibits a well-drained soil with low water retention capacity and hence is relatively dry. In both cases, BSCs were found as 'cushions' with little connection to the soil itself. On 'AB01' the substratum is glacier till, and soil development is clearly visible as are connections of biota to the soil, especially by bryophytes. This site, due to an almost top-slope position, has to rely on precipitation, but water retention potential is far better than in the storm beach site. The logged temperature regime in $5 \mathrm{~cm}$ soil depth at 'Ardley Palaeo' and 'AB01' (February 2012 to February 2014) revealed comparable conditions between the two sites, while ' $\mathrm{AB} 01^{\prime}$ ' was slightly more extreme $\left(\mathrm{T}_{\min }\right.$ : $-15^{\circ} \mathrm{C}$, $\mathrm{T}_{\max }: 8^{\circ} \mathrm{C}$, yearly average: $-2.35^{\circ} \mathrm{C}$ ) than 'Ardley Palaeo' 


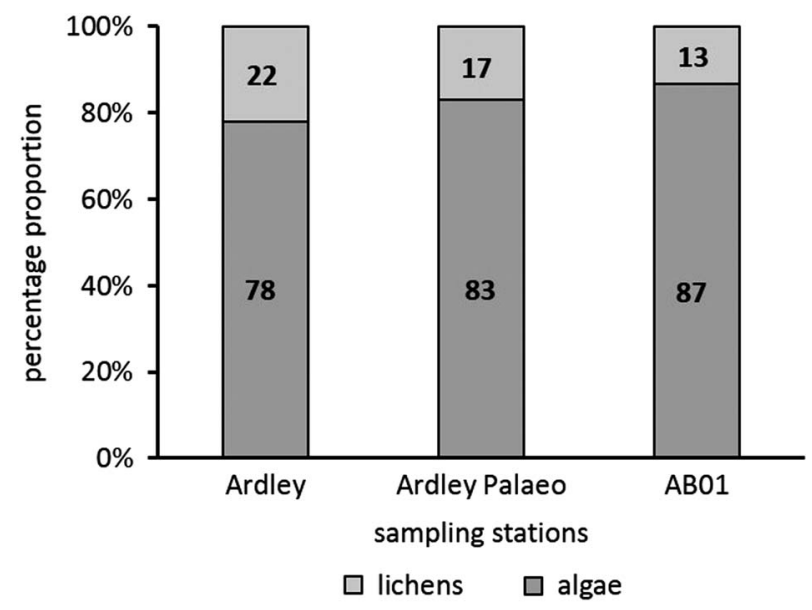

Fig. 2. Percentage proportion of microalgae and lichens in the three biological soil crust samples from the Maritime Antarctic.

( $\mathrm{T}_{\text {min }}:-13^{\circ} \mathrm{C}, \mathrm{T}_{\max }: 6.5^{\circ} \mathrm{C}$, yearly average: $-2.25^{\circ} \mathrm{C}$ ) and had a roughly two weeks shorter period of temperatures $>0^{\circ} \mathrm{C}$ in the soil between the end of November and late March (early April for 'Ardley').

\section{Strain isolation and culture conditions}

The collected BSCs were used for a comprehensive screening of all occurring eukaryotic algae and lichens. Subsamples of the BSCs were incubated in defined media to establish enrichment cultures. All cultures and later algal isolates were grown on solid 1.5\% Difco Agar (Becton Dickinson, Heidelberg, Germany) made with Bold's Basal Media and vitamins (Starr \& Zeikus 1993) modified by tripled nitrate concentration $(3 \mathrm{~N}-\mathrm{BBM}+\mathrm{V})$. They were kept at $15^{\circ} \mathrm{C}, 30 \mu \mathrm{mol}$ photons $\mathrm{m}^{-2} \mathrm{~s}^{-1}$ under a 16:8 h light:dark cycle (Osram Daylight Lumilux Cool White lamps L36W/840). The enrichment cultures were regularly screened for algal growth and colonies

Table I. Diversity indices. Jaccard index and Sørensen index are defined from 0 to 1 ( 0 = no similarity, $1=$ highest similarity $)$.

\begin{tabular}{lccc}
\hline & $\begin{array}{c}\text { 'Ardley'-Ardley 'Ardley'-AB01' } \\
\text { Palaeo' }\end{array}$ & $\begin{array}{c}\text { 'Ardley } \\
\text { Palaeo'-AB01' }\end{array}$ \\
\hline Algae & & 62 & 61 \\
$\quad \beta$-diversity & 67 & 0.155 & 0.136 \\
Jaccard index & 0.134 & 0.269 & 0.239 \\
Sørensen index & 0.236 & 12 & \\
Lichens & & 0.185 & 12 \\
$\beta$-diversity & 14 & 0.313 & 0.111 \\
Jaccard index & 0.171 & & 0.200 \\
Sørensen index & 0.294 & 74 & 73 \\
Total & & 0.161 & 0.132 \\
$\beta$-diversity & 81 & 0.277 & 0.234 \\
Jaccard index & 0.142 & & \\
Sørensen index & 0.248 & & \\
\hline
\end{tabular}

transferred with a metal needle to a new agar plate using a stereo microscope (ZS40, Olympus, Tokyo, Japan) with a magnification of 400x. For further purification the growth of the colonies was frequently monitored and several subcultures were generated under sterile conditions. After the purification step no contamination with other algae or fungi was detected. Sixty-six strains were isolated and are held in the culture collection at the University of Rostock. Using a light microscope (BX51, Olympus, Tokyo, Japan) with a magnification of $1000 \mathrm{x}$ the isolated strains were identified to the species or at least the genus level. Identification was mainly based on the identification key of Ettl \& Gärtner (2014). Other identification literature is presented in Table $\mathrm{S} 1$ found at http://dx.doi.org/10.1017/S0954102016000638. Mucilage, as one identification feature, was visualized with an aqueous solution of methylene blue. Furthermore, light micrographs were taken with an Olympus UC30 camera attached to the microscope and processed with the software cellSens Entry (Olympus, Tokyo, Japan). Additionally, hand drawings were made of the morphological features for some algal species (Table S1).

\section{Identification of diatoms}

In addition to the light microscopy, combusted permanent slides were prepared and used for the identification of diatoms. Based on their siliceous cell walls, identification is also possible after the cell death, as species-specific features, such as cell shape, pores,

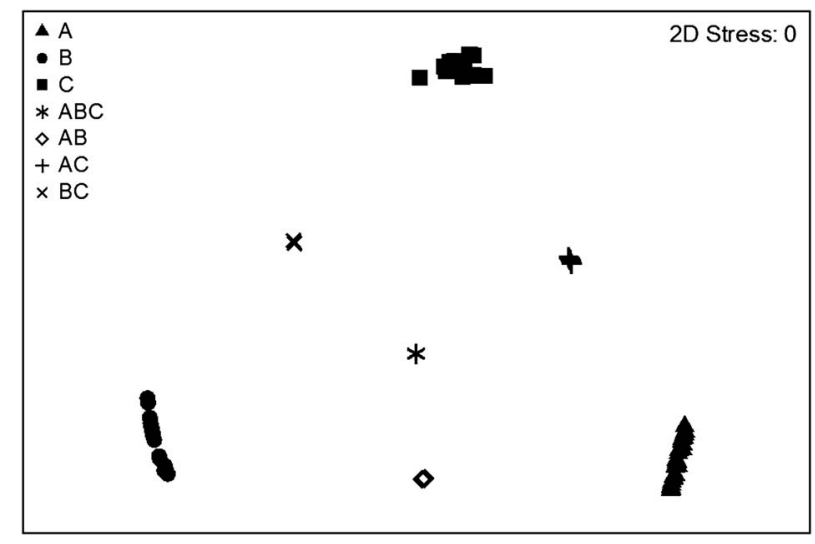

Fig. 3. MDS plot based on square root transformed data and Bray-Curtis similarity. Comparison of all three sample sites by species composition (microalgae and lichens). An MDS plot is dimensionless and visualizes the relationship of each datapoint to another. Distances between points represent the similarity/difference between all identified taxa. The stress value represents the quality of the graph $(0=$ perfect, $0.05=$ good, 0.2 = poor). A: 'Ardley', B: 'Ardley Palaeo', $\mathrm{C}$ : 'AB01', ABC: all species from all sample sites, AB: species from 'Ardley' and 'Ardley Palaeo', AC: species from 'Ardley' and 'AB01', BC: species from 'Ardley Palaeo' and 'AB01'. 
Table II. List of all identified algae species associated with biological soil crust samples from the Maritime Antarctic. $\mathrm{x}=$ presence of the respective algae species. Species authorities can be found in Table S1.

\begin{tabular}{|c|c|c|c|}
\hline Species & 'Ardley' & $\begin{array}{l}\text { 'Ardley } \\
\text { Palaeo' }\end{array}$ & 'AB01' \\
\hline \multicolumn{4}{|l|}{ Chlorophyceae } \\
\hline Chlamydomonas sp. & $\mathrm{x}$ & & \\
\hline Chlorococcum sp. & & $\mathrm{x}$ & \\
\hline Chloromonas sp. & & $\mathrm{x}$ & \\
\hline Chlorosarcina sp. & $\mathrm{x}$ & $\mathrm{x}$ & $\mathrm{x}$ \\
\hline Chlorococcum lobatum & & $\mathrm{x}$ & \\
\hline Chlorococcum cf. infusionum & & $\mathrm{x}$ & \\
\hline Chlorococcum sp. & $\mathrm{x}$ & $\mathrm{x}$ & $\mathrm{x}$ \\
\hline $\begin{array}{l}\text { Desmodesmus abundans } \\
\quad \text { (Chlorella fusca) }\end{array}$ & & $\mathrm{x}$ & \\
\hline Gloeocystis sp. & & $\mathrm{x}$ & \\
\hline $\begin{array}{l}\text { Lobochlamys cf. culleus } \\
\quad \text { (Chlamydomonas culleus) }\end{array}$ & & $\mathrm{x}$ & \\
\hline $\begin{array}{l}\text { Mychonastes homosphaera } \\
\text { (Chlorella homosphaera, } \\
\text { C. minutissima) }\end{array}$ & $\mathrm{x}$ & $\mathrm{x}$ & \\
\hline $\begin{array}{l}\text { Mychonastes cf. homosphaera } \\
\text { (C. homosphaera, } \\
\text { C. minutissima) }\end{array}$ & & $\mathrm{x}$ & \\
\hline $\begin{array}{l}\text { Neocytis } \mathrm{cf} \text {. brevis } \\
\quad \text { (Nephrodiella } \mathrm{cf} \text {. brevis) }\end{array}$ & $\mathrm{x}$ & $\mathrm{x}$ & $\mathrm{x}$ \\
\hline Neocystis sp.1 & & $\mathrm{x}$ & \\
\hline Neocytis sp.2 & $\mathrm{x}$ & $\mathrm{x}$ & $\mathrm{x}$ \\
\hline Neocystis sp. 3 & & $\mathrm{x}$ & \\
\hline Poloidion sp. & $\mathrm{x}$ & $\mathrm{x}$ & \\
\hline $\begin{array}{l}\text { Pseudodictyochloris } \\
\text { multinucleata }\end{array}$ & $\mathrm{x}$ & $\mathrm{x}$ & \\
\hline Radiococcacea gen. sp. & & & $\mathrm{x}$ \\
\hline Radiococcus $\mathrm{cf}$. signiensis & $\mathrm{x}$ & & \\
\hline Radiococcus $\mathrm{sp}$. & & $\mathrm{x}$ & \\
\hline \multicolumn{4}{|l|}{ Trebouxiophyceae } \\
\hline $\begin{array}{l}\text { Chlorella chlorelloides } \\
\text { (Dictyosphaerium } \\
\text { chlorelloides) }\end{array}$ & & & $\mathrm{x}$ \\
\hline Chlorella vulgaris & & & $\mathrm{x}$ \\
\hline Chlorella sp. & & & $\mathrm{x}$ \\
\hline Coccomyxa simplex & $\mathrm{x}$ & & \\
\hline Coccomyxa sp. & $\mathrm{x}$ & $\mathrm{x}$ & $\mathrm{x}$ \\
\hline Desmococcus olivaceus & & & $\mathrm{x}$ \\
\hline Desmococcus sp. & & & $\mathrm{x}$ \\
\hline Diplosphaera chodatii & & & $\mathrm{x}$ \\
\hline Diplosphaera cf. mисоsa & & & $\mathrm{x}$ \\
\hline Elliptochloris bilobata & $\mathrm{x}$ & & $\mathrm{x}$ \\
\hline Muriella sp. & $\mathrm{x}$ & & \\
\hline Myrmecia bisecta & & & $\mathrm{x}$ \\
\hline Myrmecia macronucleata & $\mathrm{x}$ & & $\mathrm{x}$ \\
\hline $\begin{array}{l}\text { Parietochloris cf. alveolaris } \\
\text { (Ettlia } \mathrm{cf} \text {. alveolaris) }\end{array}$ & & $\mathrm{x}$ & \\
\hline Stichococcus allas & & $\mathrm{x}$ & \\
\hline Stichococcus cf. allas & & & $\mathrm{x}$ \\
\hline Stichococcus bacillaris & & $\mathrm{x}$ & \\
\hline Stichococcus chlorelloides & $\mathrm{x}$ & & $\mathrm{x}$ \\
\hline Stichococcus sp. & & & $\mathrm{x}$ \\
\hline Trochiscia granulata & $\mathrm{x}$ & & \\
\hline \multicolumn{4}{|l|}{ Klebsormidiophyceae } \\
\hline Interfilum sp. & & & $\mathrm{x}$ \\
\hline Klebsormidium cf. bilatum & $\mathrm{x}$ & & \\
\hline Klebsormidium cf. dissectum & & $\mathrm{x}$ & $\mathrm{x}$ \\
\hline Klebsormidium cf. flaccidum & $\mathrm{x}$ & $\mathrm{x}$ & $\mathrm{x}$ \\
\hline Klebsormidium cf. subtile & & & $\mathrm{x}$ \\
\hline Klebsormidium cf. montanum & $\mathrm{x}$ & & $\mathrm{x}$ \\
\hline Klebsormidium cf. nitens & $\mathrm{x}$ & & \\
\hline
\end{tabular}

Klebsormidium sp.1

Klebsormidium $\mathrm{sp} .2$

Xanthophyceae

Chlorellidium sp.

Chlorocloster $\mathrm{cf}$. inaequalis

Chlorellidium cf. tetrabotrys

Heterococcus sp.

Pleurochloris

pseudopolychloris

Xanthonema sp.

Eustigmatophyceae

Eustigmatos cf. vischeri

Bacillariophyceae

Aulacoseira sp.

Cocconeis californica var.

kerguelensis

Cocconeis fasciolata

Cocconeis melchioroides

Cocconeis pinnata var. mattsii

Diadesmis cf. vidalii

Eunotia ralitsae

Eunotia sp.1

Eunotia sp.2

Gomphonema olivaceum $\quad \mathrm{x}$

Gomphonema sp.

Gomphonemopsis sp.

Hantzschia sp.

Luticola caubergsii

Luticola nivalis

Luticola cf. nivalis

Melosira dickiei

Navicula cf. perminuta

Navicula sp.

Nitzschia sp.

Orthoseira roeseana

Pinnularia cf. acidophila

Pinnularia borealis

Pinnularia borealis var. scalaris

Pinnularia divergentissima

Pinnularia cf. divergentissima

Pinnularia microstauron

Pinnularia cf. microstauron

Pinnularia obscura

Pinnularia cf. obscura

Pinnularia cf. subantarctica var. elongata

Pinnularia sp.

Planothidium linkei

Psammothidium germanii

Psammothidium manguinii

Psammothidium cf.

oblongellum

Pseudogomphonema

kamtschaticum

Pseudogomphonema $\mathrm{cf}$.

kamtschaticum

Stauroforma exiguiformis

Stauroforma cf. exiguiformis

Thalassiosira gracilis var. expecta

Thalassiosira gracilis $\quad \mathrm{x}$

Diatom sp.1

Diatom sp.2

Diatom sp.3

Diatom sp.4

Diatom sp.5

Diatom sp.6

Diatom sp.7 


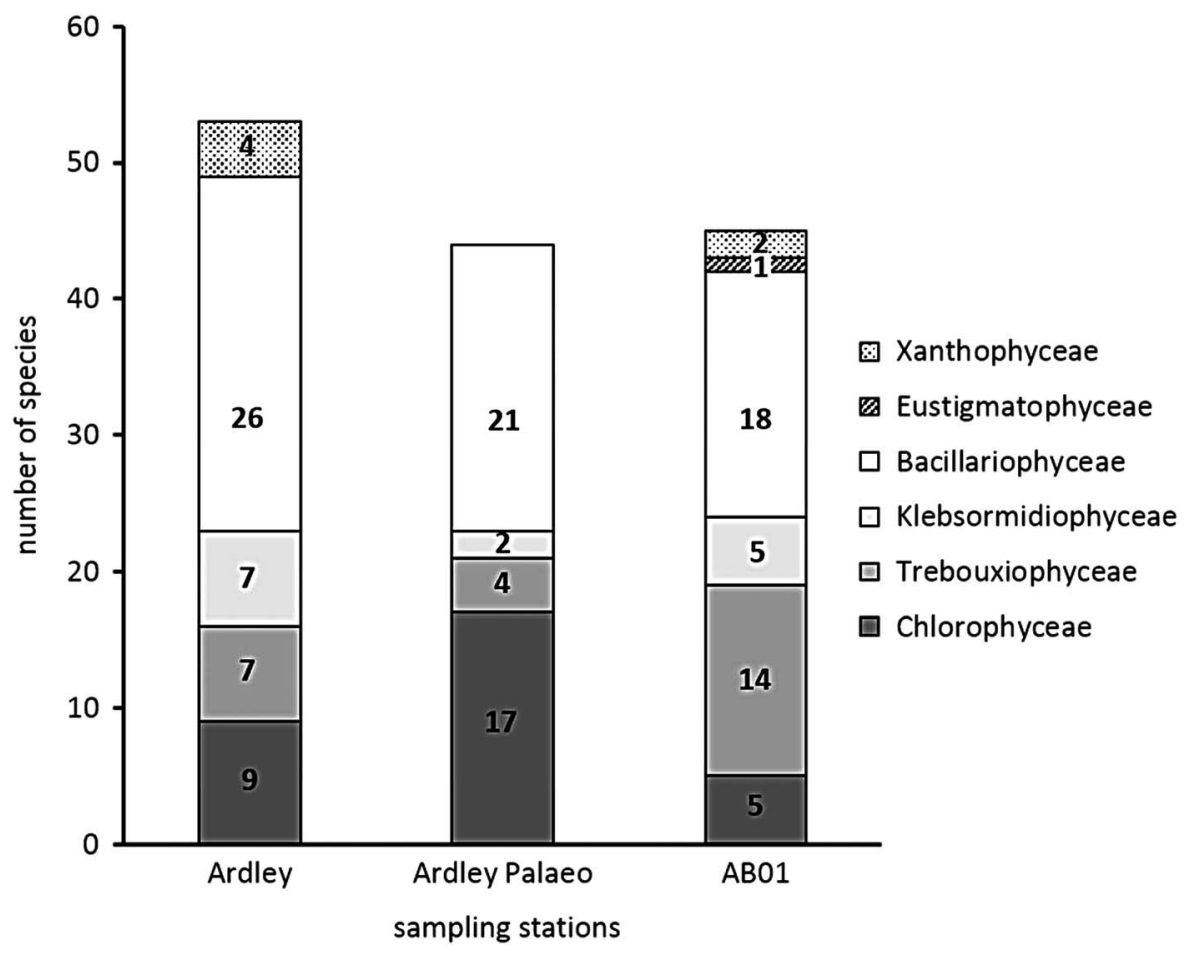

Fig. 4. Total number of green algae species (Chlorophyceae, Trebouxiophyceae, Klebsormidiophyceae, Bacillariophyceae,

Eustigmatophyceae and Xanthophyceae) in the three biological soil crust communities from the Maritime Antarctic samples.

ribs, spines and marginal ridges, are still visible. Approximately $0.5 \mathrm{~g}$ of crust material was mixed with c. $4 \mathrm{ml}$ distilled water and strongly shaken for $10 \mathrm{~min}$. Subsequently $100 \mu \mathrm{l}$ of the overlaying water was transferred onto glass cover slips using an Eppendorf pipette and air dried. This step was repeated a second time. Afterwards, the cover slips were combusted in a muffle oven (Elektra M26) at $550^{\circ} \mathrm{C}$ for $35 \mathrm{~min}$, cooled down and put onto slides with Naphrax as a mounting medium. Light micrographs were taken at a magnification of 1000x using a light microscope (BX51, Olympus, Tokyo, Japan) with an Olympus UC30 camera attached and the cellSens Entry program (Olympus, Tokyo, Japan). Additional light micrographs were acquired with a Zeiss Axio Imager. M2 with an implemented AxioCam HRc (Zeiss, Oberkochen, Germany). The literature used for diatom identification is detailed in Table S1.

\section{Identification of lichens}

For identification of lichens, morphology and anatomy were studied using a stereomicroscope and compound microscope. The nomenclature of Antarctic lichen species followed the identification key of Øvstedal \& Lewis Smith (2001). Herbar specimens of lichen species are held in the private herbarium of $U$. Schiefelbein. Characteristic lichen substances were used as chemotaxonomical markers and analysed by thin layer chromatography (TLC) in solvent system A according to the standard approach of Orange et al. (2001).

\section{$\beta$-diversity}

The $\beta$-diversity is a measure of change in species composition between habitats or variations of environmental conditions, such as temperature or moisture gradients. For this purpose, the number of species is considered unique to each habitat. The $\beta$-diversity is high if the number of species common to both habitats is low and vice versa. The following formula (Whittaker 1970) can be used for the calculation using the presence-absence data:

$$
\beta=\left(\mathrm{S}_{1}-\mathrm{c}\right)+\left(\mathrm{S}_{2}-\mathrm{c}\right)
$$

where $S_{1}$ is the total number of species recorded in the first habitat, $S_{2}$ is the total number of species recorded in the second habitat and $\mathrm{c}$ is the number of species common to both communities.

\section{Jaccard index and Sørensen index}

The Jaccard index (1902; SI ${ }_{\mathrm{J}}$ ) and Sørensen index (1948; $\mathrm{SI}_{\mathrm{S}}$ ) are similarity coefficients that measure the similarity 
Table III. List of all identified lichen species associated with biological soil crust samples from the Maritime Antarctic. $x=$ presence of the respective lichen species.

\begin{tabular}{|c|c|c|c|}
\hline Species & ‘Ardley' & $\begin{array}{l}\text { 'Ardley } \\
\text { Palaeo' }\end{array}$ & 'AB01' \\
\hline Cladonia borealis S. Stenroos & $\mathrm{x}$ & & $\mathrm{x}$ \\
\hline $\begin{array}{l}\text { Cladonia chlorophaea (Flörke ex } \\
\text { Sommerf.) Spreng. }\end{array}$ & $\mathrm{x}$ & & \\
\hline Cladonia gracilis (L.) Willd. & $\mathrm{x}$ & $\mathrm{x}$ & \\
\hline Cladonia squamosa (Scop.) Hoffm. & & $\mathrm{x}$ & \\
\hline Himantormia lugubris (Hue) I. M. Lamb & $\mathrm{x}$ & $\mathrm{x}$ & \\
\hline Lecidea sp.1 & $\mathrm{x}$ & & \\
\hline Lecidea $\mathrm{sp} .2$ & $\mathrm{x}$ & & \\
\hline $\begin{array}{l}\text { Lepraria alpina (B. de Lesd.) Tretiach \& } \\
\text { Baruffo }\end{array}$ & $\mathrm{x}$ & $\mathrm{x}$ & \\
\hline Lepraria straminea Vain. & $\mathrm{x}$ & & $\mathrm{x}$ \\
\hline Melanotopelia sp. (new species) & $\mathrm{x}$ & & \\
\hline Ochrolechia frigida (Sw.) Lynge & $\mathrm{x}$ & $\mathrm{x}$ & $\mathrm{x}$ \\
\hline Pertusaria pseudoculata Øvstedal & & $\mathrm{x}$ & \\
\hline Placopsis parallina (Nyl.) I.M. Lamb & & & $\mathrm{x}$ \\
\hline Psoroma hypnorum (Vahl) Gray & $\mathrm{x}$ & $\mathrm{x}$ & $\mathrm{x}$ \\
\hline $\begin{array}{l}\text { Rinodina olivaceobrunnea (C.W. Dodge) } \\
\text { G.E. Baker }\end{array}$ & $\mathrm{x}$ & & $\mathrm{x}$ \\
\hline Sphaerophorus globosus (Huds.) Vain. & & $\mathrm{x}$ & \\
\hline Stereocaulon alpinum Laurer & $\mathrm{x}$ & & \\
\hline Stereocaulon glabrum (Müll. Arg.) Vain. & & & $\mathrm{x}$ \\
\hline Usnea antarctica Du Rietz & $\mathrm{x}$ & & \\
\hline Usnea aurantiaco-atra (Jacq.) Bory & $\mathrm{x}$ & & \\
\hline Usnea sphacelata $\mathrm{R}$. Br. & & $\mathrm{x}$ & \\
\hline
\end{tabular}

of sets. In order to calculate the $\mathrm{SI}_{\mathrm{J}}$, the size of the intersection is divided by the size of the union of the sample set. The indices scales are defined from 0 to 1 , where the closer to 1 , the higher the similarity. The $\mathrm{SI}_{\mathbf{J}}$ and $\mathrm{SI}_{\mathrm{S}}$ are calculated using the following formulae:

$$
\begin{gathered}
\mathrm{SI}_{\mathrm{J}}=\mathrm{a}(\mathrm{a}+\mathrm{b}+\mathrm{c})^{-1}, \\
\mathrm{SI}_{\mathrm{S}}=2 \mathrm{a}(2 \mathrm{a}+\mathrm{b}+\mathrm{c})^{-1},
\end{gathered}
$$

where $\mathrm{a}$ is the number of species common to both communities, $b$ is the total number of species recorded in the first habitat and $\mathrm{c}$ is the total number of species recorded in the second habitat.

\section{Multivariate statistics}

The species composition found at the different localities was compared using the multivariate analysis of the statistical program PRIMER 6. Non-metric multidimensional scaling (MDS; Kruskal \& Wish 1978) was based on square root transformed data and BrayCurtis similarity. An MDS plot is dimensionless and visualizes the relationship of each datapoint to another. The significance of similarity was tested by using the ANOSIM permutation test (Clarke \& Green 1988, Clarke 1993). This test calculates a global measure R, which ranges between 0 and 1 and constitutes some degree of discrimination between treatments. If $\mathrm{R}=0$ there are no differences between the sample stations based on their species composition. If $\mathrm{R}=1$ the sample stations differ from each other. The stress value represents the quality of the graph $(0=$ perfect, $0.05=$ good, $0.2=$ poor $)$.

\section{Results}

Total species composition, diversity and localities

The BSCs of the King George and Ardley islands were exclusively composed of both various microalgal groups and lichens, although they were dominated by the speciesrichness of algae (78-87\%) (Fig. 2).

The total community $\beta$-diversity for all BSC samples ranged from $73-81$, and similarity was very low $\left(\mathrm{SI}_{\mathrm{J}}<0.2\right.$, $\mathrm{SI}_{\mathrm{S}}<0.3$ ). It should be emphasized that the total biodiversity indices values for 'Ardley'-AB01' were noticeable higher relative to the other comparisons (Table I).

The MDS analysis resulted in three clearly separated clusters that showed conspicuous grouping by sample site (Fig. 3). The BSC species composition of the three sample sites were significantly different as confirmed by the ANOSIM test with a global $\mathrm{R}$ of $1, p=0.001$ and a stress value of 0 .

\section{Species composition and diversity of algae}

Overall, 106 algal species were found in the BSC communities of the Ardley and King George islands. Of these, 41 species belonged to Chlorophyta (21 species were Chlorophyceae, 20 species were Trebouxiophyceae). Nine species were identified as Streptophyta and 56 species were determined as Heterokontophyta; it should be noted that 49 of these species were diatoms (Table II, Fig. 4). Species names, light micrographs, drawings and further information are summarized in an algae catalogue (Table S1 found at http://dx.doi.org/ 10.1017/S0954102016000638).

Nine species from six genera were found in all of the BSC samples: Chlorosarcina sp., Chlorococcum sp., Coccomyxa sp., Klebsormidium cf. flaccidum (Kützing) Silva, Mattox \& Blackwell, Neocytis cf. brevis (Vischer) Kostikov \& Hoffmann, Neocytis sp., Pinnularia cf. acidophila Hofmann \& Krammer, Pinnularia borealis Ehrenberg, Pinnularia borealis var. scalaris (Erenberg) Rabenhorst.

'Ardley' contained 53 species including 30 taxa that were only found at this sampling station. The species composition was dominated by diatoms (26 species).

There were 44 species identified in the BSC samples from 'Ardley Palaeo' of which 25 taxa were only found at this site. The most abundant species belong to diatoms (21 taxa) and Chlorophyceae (17 taxa). 
There were 45 species, including 25 habitat-specific species, identified from 'AB01'. Diatoms (16 species) and Trebouxiophyceae (14 species) were the most abundant in these BSCs.

A comparison of the total species numbers for each sample site showed no distinct differences. However, 'Ardley' had the highest number of species, $c$. nine species more than both of the other sites. There were high numbers of microalgal species that were unique to each sample site. Therefore, a comparison of the common species gave very low values (5-9 species per two sampling sites). All of the BSC communities were dominated by diatoms, with very similar species numbers but differing in the proportion of green algae taxa.

The $\beta$-diversity of the algal composition for the three sample sites varied between 61 and 67 (Table I). Again the similarity between the BSCs was low $\left(\mathrm{SI}_{\mathrm{J}}<0.2, \mathrm{SI}_{\mathrm{S}}<0.3\right.$; Table I). However, the similarly between 'Ardley'-'AB01' was higher than the others (Table I).

\section{Species composition and diversity of lichens}

There were 21 lichen species from 13 genera identified from all BCSs (Table III). Interestingly, only Ochrolechia frigida and Psoroma hypnorum were found at all sample sites.

The BSCs from 'Ardley' contained 15 lichen taxa; of which, seven species were only determined at this site. Nine lichen species, including four habitat-specific species, were identified from 'Ardley Palaeo'. Five species were present in 'AB01'; of which, only two species were exclusively found at this site.

The incidence of common lichen species was very low, especially in the samples from 'AB01' and 'Ardley Palaeo' (two common species).

The $\beta$-diversity ranged between 12 and 14; however, it should be noted that only two common lichen species existed in the BSC samples from 'Ardley Palaeo'-AB01' (Table I). The similarity indexes were very low $\left(\mathrm{SI}_{\mathrm{J}}<0.2, \mathrm{SI}_{\mathrm{S}} \leq 0.3\right)$. Moreover, both values for 'Ardley Palaeo'-'AB01' were noticeable lower than the others (Table I).

\section{Discussion}

This study revealed a remarkably high biodiversity of microalgae and lichens in BSC communities collected on the King George and Ardley islands (127 species). Studies have reported wide ranging species numbers for algae in BSCs, ranging from only a few to $c .100$ taxa, depending on the habitat. Büdel et al. (2009) identified 30 eukaryotic algal species in the Namib Desert, while Schulz et al. (2016) determined 106 species from coastal sand dunes at the Baltic Sea. Similar studies on algae associated with
BSCs in the Polar Regions are missing. Nevertheless, there are some data from surveys on terrestrial or soil algae at high latitudes. Soil samples from Arctic Svalbard partly covered by vascular plants and mosses contained 33 (Kaštovská et al. 2007) or 23 (Kim et al. 2008) eukaryotic algal species, pointing to a rather low diversity. Elster et al. (1999) identified 84 eukaryotic soil algae in the polar desert of central Ellesmere Island, Canada. In soil samples from Continental Antarctica, only ten chlorophytes and one diatom taxon were found (Broady \& Weinstein 1998), and these species were not associated with a BSC community. Zidarova (2008) reported 286 algal species in samples from Livingston Island, Maritime Antarctic. However, this speciesrichness can be explained by sampling from all available habitats, including soil, lakes, ponds and rocks. In the soil samples alone, 78 eukaryotic algal species were identified; of which, 66 taxa were diatoms (Zidarova 2008). When compared with all the available literature, the data found during this study point to a surprisingly high speciesrichness of terrestrial eukaryotic algae (106 species) associated with BSCs in the Maritime Antarctic.

The proportion of diatom species in the BSCs was very high (49 species) in comparison to the number of the other algal taxa. Diatoms are not always systematically studied in BSC samples, depending on the expertise and interests of the investigators, and hence making comparisons with published data can be difficult. In Continental Antarctica only one (Broady \& Weinstein 1998) to two diatom species were found (Souffreau et al. 2013), while ten species occurred in the soil of the Arctic desert of central Ellesmere Island (Elster et al. 1999). Flechtner et al. (2008) demonstrated notably few diatom species $(n=8)$ in a study of BSCs in western North America, while Schulz et al. (2016) prepared specific diatom slides for their identification, a quality approach which seems to be neglected in many investigations of BSCs, and reported 55 diatom species in BSCs from sand dunes along the Baltic Sea coast. These data confirm those of the present study. Whether all the recorded diatom species associated with the Antarctic BSCs represent actual components of BSC communities is unknown. Diatoms and other microalgae are known to be transported through the air over hundreds of kilometres in the Arctic region (Darby et al. 1974). This is especially apparent near beaches, where marine and brackish water diatoms can be windblown during stormy conditions (Lee \& Eggleston 1989). Therefore, it cannot be excluded that some of the identified diatom taxa were transported by wind (sea-spray) or waves and therefore only temporary visitors in the Antarctic BSCs. However, in the current study, material from the whole BSC was used and thus lower parts of BSC were included.

The lichen diversity (21 species) of the King George and Ardley islands represent a subset of the 110 species 
reported by Sancho et al. (1999) in their survey of all habitats on Livingston Island. Floristic studies from Victoria Land also revealed a high lichen diversity of 29 (Seppelt et al. 2010), 54 (Cannone \& Seppelt 2008) and even 59 species (Green et al. 2015). There are indications that the species-richness of lichens varies based on latitudes, and hence it was suggested to subdivide Maritime and Continental Antarctica into different phytogeographical regions (Peat et al. 2007).

In summary, the data presented show a high species diversity of microalgae and lichens associated with BSCs, which differed between the sample sites. The sites could therefore be distinguished by a specific species composition. Interestingly, 'Ardley' revealed a higher similarity to 'AB01' (King George Island) for algae diversity. However, the similarity of 'Ardley Palaeo' to 'AB01' was lower for lichen diversity. This striking difference can be explained by (micro)habitat-specific conditions. It is known that algae and lichens found in soil prefer different substrates and that the availability of water is an important environmental factor for their occurrence. The habitats investigated in this study differed by substrate, topography and moisture. Consequently, the data presented indicate that the species composition of BSC communities in Maritime Antarctic is controlled by micro-environmental conditions. Moreover, it provides the first overview of BSC-associated algal and lichen taxa in the southern Polar Regions.

\section{Acknowledgements}

This study was funded by the DFG project 'Polarcrust' (KA899/23-1) of the Priority Program 1158 'Antarctic Research' (DFG: Deutsche Forschungsgemeinschaft). We are grateful to the Botanic Garden and Botanical Museum Berlin-Dahlem for technical support for the lichen and diatom identification. Special thanks to Dr Lydia Gustavs for initiating co-operation with lichenologists. The authors also thank Karoline Schulz for preparation of diatom slides and taking several light micrographs of these diatoms. Many thanks to the reviewers for the constructive criticism and suggestions. TM thanks the Alexander von Humboldt Foundation for financial support. We also thank the Instituto Antártico Chileno for their logistic support.

\section{Author contribution}

NB cultivated and isolated green and yellow-green algae, identified these species, took light micrographs, made hand drawings, created figures and tables, calculated biodiversity indices, performed the statistical analyses and wrote the manuscript. US identified lichens by microscopy and TLC. NA identified diatoms and took light micrographs. JB collected samples, measured soil temperatures and wrote part of the 'Materials and methods' section. TM identified green and yellow-green algae species. HJMS identified lichens, performed TLC and provided technical support for the lichen identification. UK wrote some parts of the manuscript and provided technical support.

\section{Supplemental material}

A supplemental table presenting the algae catalogue will be found at http://dx.doi.org/10.1017/S0954102016000638.

\section{References}

BeLnAP, J. 2006. The potential roles of biological soil crusts in dryland hydrologic cycles. Hydrological Processes, 20, 10.1002/hyp.6325.

Belnap, J. \& Gillette, D.A. 1998. Vulnerability of desert biological soil crusts to wind erosion: the influences of crust development, soil texture, and disturbance. Journal of Arid Environments, 39, 10.1006/jare.1998.0388.

Belnap, J., Büdel, B. \& Lange, O.L. 2001. Biological soil crusts: characteristics and distribution. In Belnap, J. \& LANGe, O.L., eds. Biological soil crusts: structure, function, and management. Berlin Heidelberg: Springer, 3-30.

Boy, J., Godoy, R., Shibistova, O., Boy, D., McCulloch, R., de la Fuente, A.A., Morales, M.A., Mikutta, R. \& Guggenberger, G. 2016. Successional patterns along soil development gradients formed by glacier retreat in the Maritime Antarctic, King George Island. Revista Chilena de Historia Natural, 89, 10.1186/s40693-016-0056-8.

BroAdy, P.A. 1996. Diversity, distribution and dispersal of Antarctic terrestrial algae. Biodiversity and Conservation, 5, 10.1007/BF00051981.

Broady, P.A. \& Weinstein, R.N. 1998. Algae, lichens and fungi in La Gorce Mountains, Antarctica. Antarctic Science, 10, 10.1017/ S0954102098000467.

Büdel, B. \& Colesie, C. 2014. Biological soil crusts. In Cowan, D., ed. Antarctic terrestrial microbiology. Berlin Heidelberg: Springer, 131-161.

Büdel, B., Darienko, T., Deutschewitz, K., Dojani, S., Friedl, T., Mohr, K.I., Salisch, M., Reisser, W. \& Weber, B. 2009. Southern African biological soil crusts are ubiquitous and highly diverse in drylands, being restricted by rainfall frequency. Microbial Ecology, 57, 10.1007/s00248-008-9449-9.

Cannone, N. \& Seppelt, R. 2008. A preliminary floristic classification of southern and northern Victoria Land vegetation, Continental Antarctica. Antarctic Science, 20, 10.1017/S0954102008001454.

CLARKE, K.R. 1993. Non-parametric multivariate analyses of changes in community structure. Australian Journal of Ecology, 18, 117-143.

Clarke, K.R. \& Green, R.H. 1988. Statistical design and analysis for a 'biological effect' study. Marine Ecology Progress Series, 46, 213-226.

Colesie, C., Gommeaux, M., Green, T.G.A. \& Büdel, B. 2014. Biological soil crusts in Continental Antarctica: Garwood Valley, southern Victoria Land, and Diamond Hill, Darwin Mountains region. Antarctic Science, 26, 10.1017/S0954102013000291.

Darby, D.A., BurCKLe, L.H. \& Clark, D.L. 1974. Airborne dust on the Arctic ice pack, its composition and fallout rate. Earth and Planetary Science Letters, 24, 166-172.

Elster, J., Lukesová, A., Svoboda, J., Kopecky, J. \& Kanda, H. 1999. Diversity and abundance of soil algae in the polar desert, Sverdrup Pass, central Ellesmere Island. Polar Record, 35, 10.1017/ S0032247400015515.

Ettl, H. \& Gärtner, G. 2014. Syllabus der boden-, luft- und flechtenalgen. Berlin Heidelberg: Springer, 773 pp.

Evans, R.D. \& BeLnAP, J. 1999. Long-term consequences of disturbance on nitrogen dynamics in an arid ecosystem. Ecology, 80, 150-160.

Evans, R.D. \& Lange, O.L. 2001. Biological soil crusts and ecosystem nitrogen and carbon dynamics. In Belnap, J. \& LANGe, O.L., eds. Biological soil crusts: structure, function, and management. Berlin Heidelberg: Springer, 263-279. 
Flechtner, V.R., Johansen, J.R. \& Belnap, J. 2008. The biological soil crusts of the San Nicolas Island: enigmatic algae from a geographically isolated ecosystem. Western North American Naturalist, 68, 10.3398/1527-0904-68.4.405.

Green, T.G.A. \& Broady, P.A. 2001. Biological soil crusts of Antarctica. In Belnap, J. \& LANGe, O.L., eds. Biological soil crusts: structure, function, and management. Berlin Heidelberg: Springer, 133-139.

Green, T.G.A., Seppelt, R.D., Brabyn, L.R., Beard, C., Türk, R. \& LANGE, O.L. 2015. Flora and vegetation of Cape Hallett and vicinity, northern Victoria Land, Antarctica. Polar Biology, 38, 10.1007/ s00300-015-1744-6.

Harper, K.T. \& Belnap, J. 2001. The influence of biological soil crusts on mineral uptake by associated vascular plants. Journal of Arid Environments, 47, 10.1006/jare.2000.0713.

Kaštovská, K., Stibal, M., Š AbackÁ, M., Černá, B., ŠAntrưČKová, H. \& Elster, J. 2007. Microbial community structure and ecology of subglacial sediments in two polythermal Svalbard glaciers characterized by epifluorescence microscopy and PLFA. Polar Biology, 30, 10.1007/s00300-006-0181-y.

Kejna, M., Arazny, A. \& Sobota, I. 2013. Climatic change on King George Island in the years 1948-2011. Polish Polar Research, 34, 10.2478/popore-2013-0004.

KIM, G.H., KlochKova, T.A. \& Kang, S.H. 2008. Notes on freshwater and terrestrial algae from $\mathrm{Ny}$-Ålesund, Svalbard (high Arctic sea area). Journal of Environmental Biology, 29, 485-491.

Kruskal, J.B. \& Wish, M. 1978. Multidimensional scaling. A Sage University Paper series on Quantitative Applications in the Social Sciences, 07-001. Newbury Park, CA: Sage Publications, 96 pp.

Lee, T.F. \& EgGleston, P.M. 1989. Airborne algae and cyanobacteria. Grana, 28, 10.1080/00173138909431014.

MäusBaCHER, R. 1991. Die jungquartäre Relief- und Klimageschichte im Bereich der Fildeshalbinsel Süd-Shetland-Inseln. Heidelberg: Heidelberger Geographische Arbeiten, 205 pp.

Orange, A., JAmes, P.W. \& White, F.J. 2001. Microchemical methods for the identification of lichens. London: British Lichen Society, $101 \mathrm{pp}$.

Øvstedal, D.O. \& Lewis Smith, R.I. 2001. Lichens of Antarctica and South Georgia: a guide to their identification and ecology. Cambridge: Cambridge University Press, 424 pp.

Peat, H.J., Clarke, A. \& Convey, P. 2007. Diversity and biogeography of the Antarctic flora. Journal of Biogeography, 34, 10.1111/j.13652699.2006.01565.x.
Pfaff, S., Borchhardt, N., Boy, J., Karsten, U. \& Gustavs, L. 2016. Desiccation tolerance and growth-temperature requirements of Coccomyxa (Trebouxiophyceae, Chlorophyta) strains from Antarctic biological soil crusts. Algological Studies, 151/152, 10.1127/algol_stud/2016/0245.

Sancho, L.G., Schulz, F., Schroeter, B. \& Kappen, L. 1999. Bryophyte and lichen flora of South Bay (Livingston Island: South Shetland Islands, Antarctica). Nova Hedwigia, 68, 301-337.

Schulz, K., Mikhailyuk, T., Dressler, M., Leinweber, P. \& Karsten, U. 2016. Biological soil crusts from coastal dunes at the Baltic Sea: cyanobacterial and algal biodiversity and related soil properties. Microbial Ecology, 71, 10.1007/s00248-015-0691-7.

Seppelt, R.D., Türk, R., Green, T.G.A., Moser, G., Pannewitz, S., SAncho, L.G. \& Schroeter, B. 2010. Lichen and moss communities of Botany Bay, Granite Harbour, Ross Sea, Antarctica. Antarctic Science, 22, 10.1017/S0954102010000568.

Souffreau, C., Vanormelingen, P., van de Vijver, B., Isheva, T., Verleyen, E., Sabbe, K. \& Vyverman, W. 2013. Molecular evidence for distinct Antarctic lineages in the cosmopolitan terrestrial diatoms Pinnularia borealis and Hantzschia amphioxys. Protist, 164, 10.1016/j. protis.2012.04.001.

StARR, R.C. \& ZeIKUS, J.A. 1993. UTEX - the culture collection of algae at the University of Texas at Austin. 1993 list of cultures. Journal of Phycology, 29(Sup.), 1-106.

Watcham, E.P., Bentley, M.J., Hodgson, D.A., Roberts, S.J., Fretwell, P.T., Lloyd, J.M., Larter, R.D., Whitehouse, P.L., Leng, M.J., Monien, P. \& Moreton, S.G. 2011. A new Holocene relative sea level curve for the South Shetland Islands, Antarctica. Quaternary Science Reviews, 30, 10.1016/j.quascirev.2011.07.021.

Weber, B., Büdel, B. \& Belnap, B. 2016. Biological soil crusts: an organizing principle in drylands. Berlin Heidelberg: Springer, 539 pp.

WhitTAKer, R.H. 1972. Evolution and measurement of species diversity. Taxon, 21, 213-251.

Williams, L., Borchhardt, N., Colesie, C., Baum, C., KomsicBuchmann, K., Rippin, M., Becker, B., Karsten, U. \& Büdel, B. 2016. Biological soil crusts of Arctic Svalbard and of Livingston Island, Antarctica. Polar Biology, 10.1007/s00300-016-1967-1.

Wu, Y.M., RaO, B.Q., Wu, P.P., Liu, Y.D., LI, G.B. \& LI, D.H. 2013. Development of artificially induced biological soil crusts in fields and their effects on top soil. Plant and Soil, 370, 10.1007/s11104013-1611-6.

ZIDAROVA, R.P. 2008. Algae from Livingston Island (S Shetland Islands): a checklist. Phytologia Balcanica, 14, 19-35. 